
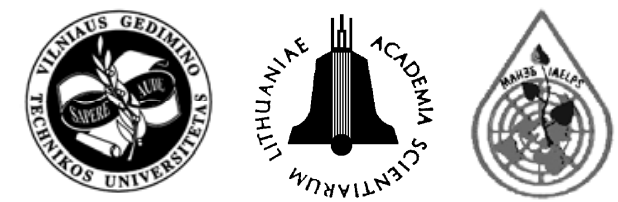

JOURNAL OF ENVIRONMENTAL ENGINEERING

AND LANDSCAPE MANAGEMENT

2010

18(3): 226-233

\title{
ESTIMATION OF SEASONAL VARIATIONS OF HARD COSMIC RAY FLUX AND ATMOSPHERIC PRESSURE IN 2004-2005
}

\author{
Dmitrijus Styro $^{1}$, Jovita Damauskaité ${ }^{2}$, Jonas Kleiza ${ }^{3}$ \\ ${ }^{1,2}$ Dept of Physics, Vilnius Gediminas Technical University, Saulètekio al. 11, LT-10223 Vilnius, Lithuania \\ ${ }^{3}$ Dept of Mathematical Modelling, Vilnius Gediminas Technical University, \\ Saulètekio al. 11, LT-10223 Vilnius, Lithuania

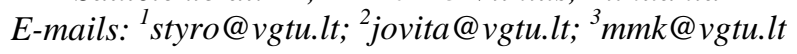 \\ Submitted 13 Jul. 2009; accepted 19 Oct. 2009
}

\begin{abstract}
This paper focuses on the analysis of connection between changes in hard cosmic ray flux (HCRF) and atmospheric pressure. To analyse connection between HCRF and atmospheric pressure change, the data of HCRF were obtained using a gamma spectrometer. The statistical data of measurements have been analysed. Detailed information on atmospheric pressure was presented by the Lithuanian Hydrometeorological Service. Correlation coefficients were calculated by performing a simple linear regression analysis between HCRF and atmospheric pressure in the same day. A strong inverse correlation during simultaneous measurements was determined. The correlation coefficients were defined for different seasons of the year. An empirical criterion of $-20 \mathrm{imp} / \mathrm{h}$ was chosen in analysis of HCRF. Connection between HCRF decrease at 1.2-1.6 MeV energy interval and the minimum atmospheric pressure in 3-6 days at individual time intervals is defined in Vilnius. The efficiency of prognosis was 59-73\% for the period 2004-2005.
\end{abstract}

Keywords: cosmic ray, atmospheric pressure, correlation coefficient, connection.

\section{Introduction}

The problem of cosmic ray space and time variations is one of the most interesting and complicated aspects of cosmic ray physics. It has been known for a long time that the intensity as well as the energy spectrum of cosmic ray is modulated by solar activity. In fact there exists an inverse correlation between cosmic ray intensity variations and solar activity. The solar activity has been shown to vary over periods of 11 and 22 years as reflected in the cyclic variation in the sunspot numbers and associated magnetic field (Usoskin and Kovaltsov 2008; Starodubtsev et al. 2004).

However, the variations of cosmic ray intensity may be dominated on long-time scales, not by global processes, but by geomagnetic field changes, which affect the cosmic ray access to the Earth (Usoskin 2004).

Cosmic rays form the main source of the atmospheric ionization in the troposphere and lower stratosphere, contributing significantly also to the ionization of higher atmospheric layers. When entering the Earth's atmospheric, very energetic cosmic rays initiate a nucleonicelectromagnetic-muon cascade in the atmosphere, thus forming secondary particles ionizing the ambient air, leading to essential physical and chemical changes in the atmosphere (Roldugin and Tinsley 2004).

Since climatic changes on the Earth have become of great concern it is pertinent to explore whether the longperiod solar variations also reflect in the variations of the climatic parameters. Further, it is also important to ex- plore whether any such climatic variations have a linkage with the geomagnetic activity (Kovaltsov and Usoskin 2007; Swensmark 1998).

The intensity of cosmic rays at the ground level (mostly muons) varies under the impact of atmospheric conditions. Besides of these phenomena of a local character, there are global reasons of cosmic ray intensity modulations determined by geophysical cyclic processes and processes related to solar activity. Thus, muon flux variations bring information about atmospheric processes (Yashin et al. 2006).

Cosmic rays are in fact the source of an almost uniform background of ionizing radiation which is present everywhere on the Earth. Most of their energy arrives to the ground in the form of kinetic energy of muons. Muons are very penetrating particles and do not interact very much with the air molecules. They lose a small fraction of their energy before reaching the ground.

Muon flux at the ground level is strongly related with different thermodynamics processes in the Earth's atmosphere at a generation level (barometric, temperature effects) and with more complex wave processes in the upper troposphere (gravitational wave of air density), correlated with different turbulent and wave processes of a geophysical origin (powerful thunderstorms, hurricanes) (Стыро 1983, 1984; Стыро, Астраускене 1988). Wave processes at the altitude of muon generation $(10-20 \mathrm{~km})$ modulate muon flux (Стыро $u$ дp. 2003; Styro et al. 2004).

First of all, a careful study of atmospheric variations is necessary to correct the observational data for such 
effects in order to find variations originating outside the Earth's atmosphere. In the second place, these variations form a valued tool for investigating variations of conditions in the terrestrial atmospheric and for understanding the interaction mechanism of high-energy primary particles passing through a thick layer of air. It is obvious that atmospheric variations have periods that reflect the periods of changes of meteorological factors (seasonal, diurnal, semi-diurnal). One of the main atmospheric variations is the barometric effect. The explanation of this effect is based on the processes of decay and nuclear interaction which take place in nuclear-meson cascade. Barometric effect is determined only by one factor, the pressure at the detection level. Atmospheric pressure variations not only depend on geographical location and its local environment, but also on the frequency of cyclonic and anti-cyclonic formations of the atmospheric circulation.

A period of a high pressure is associated with more absorber above the detector and a lower detection rate results. The purpose of this investigation is to statistically determine the connection between hard cosmic ray flux variation and atmospheric pressure change.

\section{Measurement methods}

A gamma-spectrometer with a scintillation detector was used to measure hard cosmic ray flux (HCRF) (Стыро 1984; Стыро, Астраускене 1988). The detector was placed in a lead protective chamber with $10-12 \mathrm{~cm}$ thick walls to absorb the mild component of cosmic radiation. Muons generate light micro flashes in the $\mathrm{NaI}(\mathrm{Tl})$ crystal of $6.3 \times 6.3 \mathrm{~cm}^{2}$ size. The intensity of light micro flash depends on the particle energy.

The spectrum was formed by the interaction of HCRF with the detector following Compton's scattering. The operating stability of the gamma-spectrometer was controlled by the radionuclide ${ }^{137} \mathrm{Cs}$. HCRF measurements were carried out continuously and obtained results were registered every $15 \mathrm{~min}$. The total of the obtained results is over 70000. The HCRF measurement method is published in papers (Стыро $u$ дp. 2003; Styro et al. 2004, 2005, 2007). Detailed methods of measurements of the background of a gamma-spectrometer with a scintillation detector and assessment of results are presented in papers (Сивинцев et al. 1980; Береснев et al. 1988; Стыро, Сивинцев 1983).

The meteorological data were obtained at a meteorological station of Vilnius city from the Hydrometeorological Service of Lithuania.

HCRF was analysed at time intervals of 8-9, 9-10, 11-12 and 12-13 hours.

It is necessary to use a number of empirical criteria to find short-term prognostic connection between variations of the considered parameters.

The processing of the experimental information was completed as follows:

1. The total number of cosmic particles was registered every $15 \mathrm{~min}$. at energy interval of $1.2-1.6 \mathrm{MeV}$.
2. Correlation coefficients were calculated by performing a simple linear regression analysis between daily HCRF and atmospheric pressure.

3. Correlation between HCRF decrease and atmospheric pressure decrease was analysed during a time period of 8-13 hours in 3-6 days.

4. Criterion of HCRF decrease of $-20 \mathrm{imp} / \mathrm{h}$. was proposed.

HCRF is unstable near the ground surface and depends on atmospheric pressure change, i. e. cyclonic and anti-cyclonic activity. In the case of HCRF increase, the atmospheric pressure decreases, on the contrary, when HCRF decreases the atmospheric pressure increases during the time of simultaneous measurement. The inverse correlation between the above mentioned parameters is observed. The HCRF and atmospheric pressure course was studied by Pearson's correlation coefficient $\rho$ with confidence interval. These parameters are presented by formulas (Hill and Liwecki 2007):

$$
\begin{gathered}
\rho=\frac{\sum_{i=1}^{n}\left(x_{i}-\bar{x}\right)\left(y_{i}-\bar{y}\right)}{\left(\sigma_{x} \sigma_{y}\right)}, \\
\sigma_{x}=\frac{1}{n} \sum_{i=1}^{n}\left(x_{i}-\bar{x}\right)^{2}, \sigma_{y}=\frac{1}{n} \sum_{i=1}^{n}\left(y_{i}-\bar{y}\right)^{2}, \\
\tanh \left(\arctan (\rho)-\frac{t_{p}}{\sqrt{n-3}}\right), \\
\tanh \left(\arctan (\rho)+\frac{t_{p}}{\sqrt{n-3}}\right), \\
t_{p}=F^{-1}((1+\gamma) / 2),
\end{gathered}
$$

where $x$ - hard cosmic ray flux (HCRF); $y$ - atmospheric pressure values; $\sigma_{x}, \sigma_{y}-$ standard deviations; $x_{i}, y_{i}$ - observations of variable $x, y ; \bar{x}, \bar{y}$ - average values of variable $x, y ; n$-data of observations; $F^{-1}-$ inverse cumulative density function of normal $[0,1]$ distribution; $\gamma$ - probability value.

The linear regression model between HCRF and atmospheric pressure in the same day was defined by a linear regression (Hill and Lewecki 2007):

$$
\frac{y-\bar{y}}{\sigma_{x}}=\rho \frac{x-\bar{x}}{\sigma_{y}} .
$$

The method and formulas presented above allow evaluating connection between hard cosmic ray flux and atmospheric pressure variations.

\section{Results}

The continuous measurement data of HCRF and atmospheric pressure variations were analysed in Vilnius in 2004-2005. Correlation coefficients and regression equations were solved using the MAPLE software. 
Table 1. Correlation coefficients $(\rho)$ with confidence interval between HCRF and atmospheric pressure in different seasons in 2004 and 2005

\begin{tabular}{c|c|c|c|c|c}
\hline $\begin{array}{c}\text { Seasons } \\
2004\end{array}$ & $\rho$ & 95\% confidence interval & $\begin{array}{c}\text { Seasons } \\
2005\end{array}$ & $\rho$ & 95\% confidence interval \\
\hline Winter & -0.465 & $(-0.287 ;-0.613)$ & Winter & -0.780 & $(-0.680 ;-0.848)$ \\
\hline Spring & -0.549 & $(-0.377 ;-0.684)$ & Spring & -0.641 & $(-0.497 ;-0.751)$ \\
\hline Summer & -0.505 & $(-0.319 ;-0.653)$ & Summer & -0.358 & $(-0.166 ;-0.524)$ \\
\hline Autumn & -0.648 & $(-0.448 ;-0.786)$ & Autumn & -0.507 & $(-0.336 ;-0.646)$ \\
\hline
\end{tabular}

Table 2. Correlation coefficients $(\rho)$ with confidence interval between HCRF and atmospheric pressure in different seasons during the period 2004-2005

\begin{tabular}{c|c|c}
\hline $\begin{array}{c}\text { Seasons } \\
2004-2005\end{array}$ & $\rho$ & $95 \%$ confidence interval \\
\hline Winter & -0.608 & $(-0.508 ;-0.692)$ \\
\hline Spring & -0.590 & $(-0.482 ;-0.680)$ \\
\hline Summer & -0.426 & $(-0.295 ;-0.541)$ \\
\hline Autumn & -0.598 & $(-0.480 ;-0.695)$ \\
\hline
\end{tabular}

The calculated correlation coefficients between HCRF and atmospheric pressure are presented in Table 1. They are negative. It means that HCRF and atmospheric pressure course have an inverse relationship.

The correlation degree is different at different seasons of the year. In 2004 the highest negative correlation was found in autumn $(-0.648)$, in spring $(-0.549)$, in summer $(-0.505)$. The lowest correlation was observed in winter $(-0.465)$ (Table 1$)$.

However, in 2005 the strongest negative correlation was in winter $(-0.780)$. The weakest negative correlation occurred in summer $(-0,358)$ (Table 1$)$. The highest correlation coefficient was found in winter $(-0.608)$ and the lowest correlation - in summer $(-0.426)$ during the period 2004-2005 (Table 2). The other correlation coefficients are presented in Table 2.

The obtained results for different seasons during the period 2004-2005 are illustrated in Fig. 1. Here the maximum inclination of the line refers to the winter season (Fig. 1a) and minimum - to the summer time (Fig. 1c). Almost the same inclination of regression times is observed is spring (Fig. 1b) and autumn (Fig. 1d). It means that connection between the analysed processes depends on the season in general and has a similar activity in transitional periods of the year.

A short-term prognostic correlation between HCRF variations and atmospheric pressure variations is complicated. To solve this problem it is necessary to examine HCRF course at some time intervals using an empirical criterion. An observation time interval of 8-13 hours was chosen (Стыро 1983, 1984). This time interval was divided into four time intervals. The data of HCRF decrease predict the atmospheric pressure decrease: in 3 days at a time interval of 8-9 hours, in 4 days at 9-10 hours, in 5 days at $11-12$ hours and in 6 days at $12-13$ hours. The criterion of HCRF decrease was proposed $-20 \mathrm{imp} / \mathrm{h}$.

To analyse the atmospheric pressure decrease a criterion was not used. The results of obtained prognostic connection between HCRF at 1.2-1.6 MeV energy interval and atmospheric pressure decrease in 2004 and 2005 are presented in Tables 3 and 4.

The results of Tables 3 and 4 confirmed a correlation between HCRF and atmospheric pressure decrease. The number of occurrences of obtained results are different at various time intervals in 2004 and 2005. According to the presented data in Tables 3 and 4, the prognostic connection efficiency between HCRF and atmospheric pressure decrease was 59-73\% in 2004 and 63-69\% in 2005. The highest efficiency of the presented results was $73 \%$ at a time interval of 9-10 hours.

At some time intervals in different months the efficiency of prognosis was $100 \%$, for example, in 11-12 hours in April, October and December in 2004 and in 8-9 hours in January, in 11-12 hours in March, September in 2005. In August the efficiency of prognosis was 100\% at all the time intervals in 2004.

An example of cyclone transfer towards Vilnius on 16-21 January 2005, when HCRF decrease was registered, is illustrated in Fig. 2. 
a)
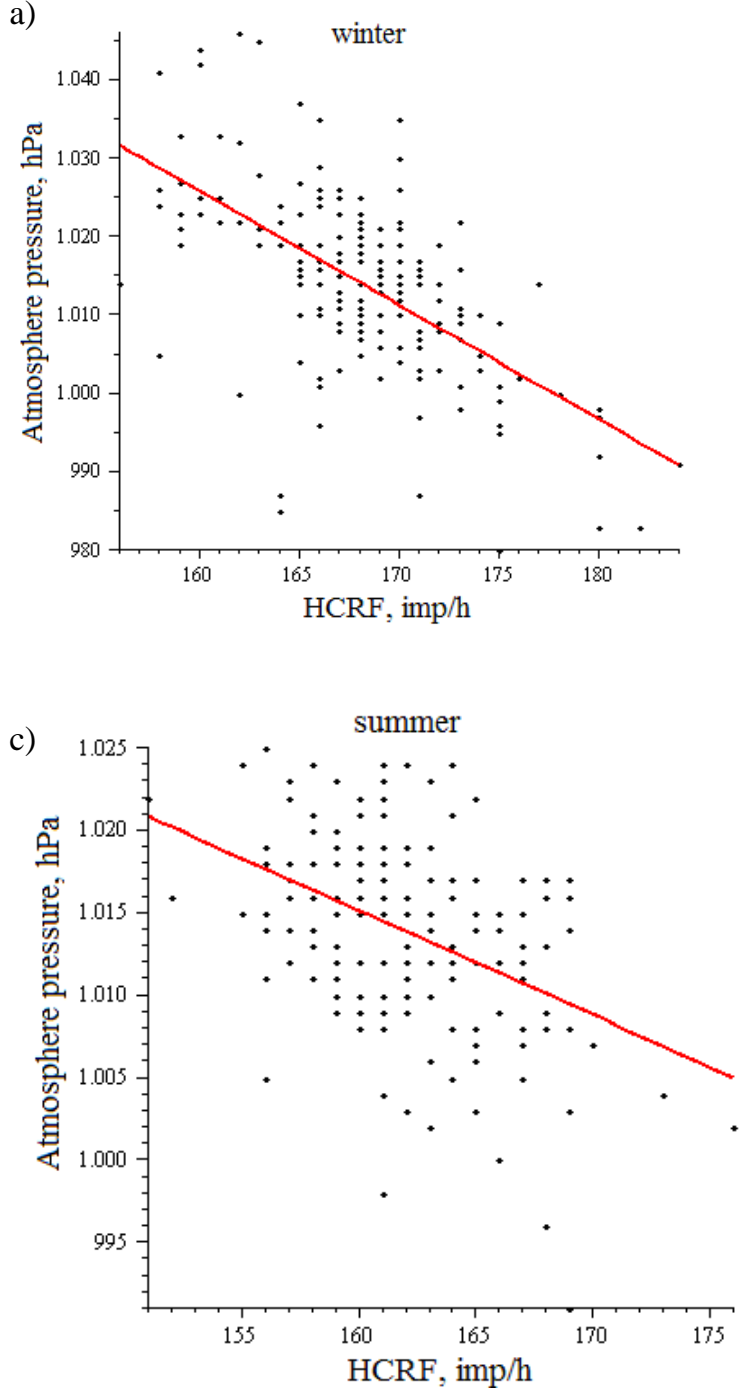

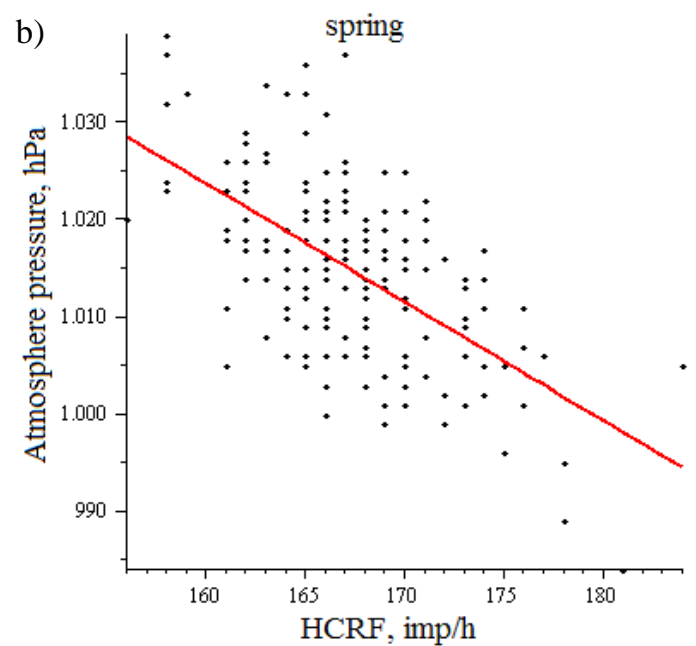

d)

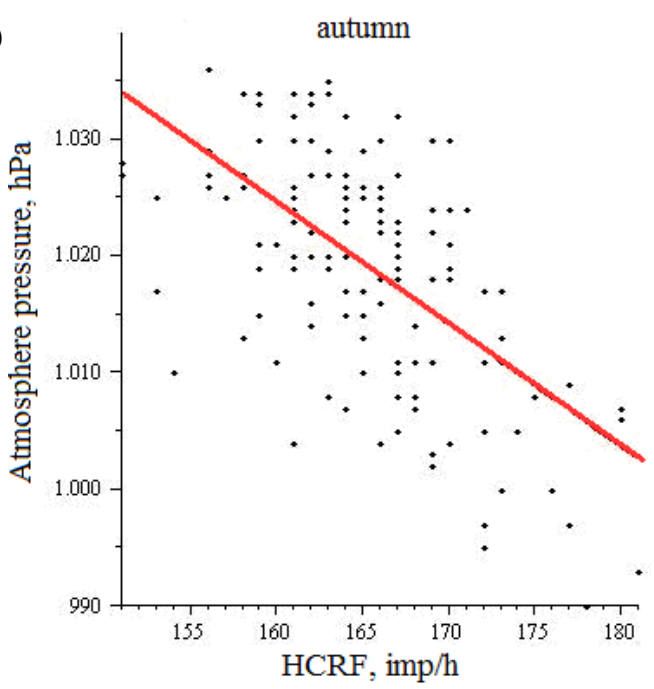

Fig. 1. Linear regressions between HCRF and atmospheric pressure in different seasons during 2004-2005: a - winter; b - spring; c -summer; d - autumn

Table 3. Efficiency of prognostic connection between HCRF decrease at 1.2-1.6 MeV energy interval and atmospheric pressure decrease at various time intervals in Vilnius in 2004

\begin{tabular}{c|c|c|c|c|c|c|c|c}
\hline \multirow{2}{*}{ Months } & \multicolumn{4}{|c|}{$\begin{array}{c}\text { Number of atmospheric } \\
\text { pressure decreases }\end{array}$} & \multicolumn{4}{c}{ Number of occurrences } \\
\cline { 2 - 9 } & $8-9$ & $9-10$ & $11-12$ & $12-13$ & $8-9$ & $9-10$ & $11-12$ & $12-13$ \\
\hline January & 4 & 7 & 3 & 3 & 3 & 6 & 2 & 3 \\
\hline February & 7 & 4 & 5 & 4 & 5 & 1 & 3 & 2 \\
\hline March & 3 & 4 & 5 & 7 & 1 & 3 & 2 & 5 \\
\hline April & 4 & 2 & 3 & 4 & 3 & 1 & 3 & 3 \\
\hline May & 4 & 6 & 5 & 2 & 2 & 5 & 2 & 1 \\
\hline June & 4 & 6 & 6 & 5 & 2 & 4 & 4 & 3 \\
\hline July & 3 & 8 & - & 5 & 1 & 7 & - & 4 \\
\hline August & 1 & 1 & 2 & 3 & 1 & 1 & 2 & 3 \\
\hline September & - & 1 & 1 & 1 & - & 1 & 0 & 0 \\
\hline October & 3 & 2 & 2 & - & 1 & 2 & 2 & - \\
\hline November & 6 & 4 & 5 & 6 & 4 & 3 & 3 & 2 \\
\hline December & 2 & 6 & 6 & 4 & 1 & 3 & 6 & 3 \\
\hline Total & $\mathbf{4 1}$ & $\mathbf{5 1}$ & $\mathbf{4 3}$ & $\mathbf{4 4}$ & $\mathbf{2 4}$ & $\mathbf{3 7}$ & $\mathbf{2 9}$ & $\mathbf{2 9}$ \\
\hline Total, \% & & & & & $\mathbf{5 9}$ & $\mathbf{7 3}$ & $\mathbf{6 7}$ & $\mathbf{6 6}$ \\
\hline
\end{tabular}


Table 4. Efficiency of prognostic connection between HCRF decrease at 1.2-1.6 MeV energy interval and atmospheric pressure decrease at various time intervals in Vilnius in 2005

\begin{tabular}{c|c|c|c|c|c|c|c|c}
\hline \multirow{2}{*}{ Months } & \multicolumn{4}{|c|}{$\begin{array}{c}\text { Number of atmospheric } \\
\text { pressure decreases }\end{array}$} & \multicolumn{4}{c}{ Number of occurrences } \\
\cline { 2 - 9 } & $8-9$ & $9-10$ & $11-12$ & $12-13$ & $8-9$ & $9-10$ & $11-12$ & $12-13$ \\
\hline January & 3 & 6 & 3 & 4 & 3 & 4 & 2 & 3 \\
\hline February & 8 & 7 & 6 & 4 & 5 & 1 & 4 & 3 \\
\hline March & 7 & 7 & 3 & 5 & 3 & 3 & 3 & 3 \\
\hline April & 6 & 7 & 7 & 5 & 3 & 2 & 5 & 4 \\
\hline May & 6 & 4 & 4 & 2 & 4 & 2 & 3 & 0 \\
\hline June & 6 & 5 & 5 & 5 & 3 & 2 & 2 & 2 \\
\hline July & 3 & 6 & 8 & 5 & 1 & 3 & 6 & 3 \\
\hline August & 2 & 6 & 5 & 4 & 1 & 4 & 2 & 4 \\
\hline September & 7 & 5 & 3 & 6 & 6 & 4 & 3 & 5 \\
\hline October & 4 & 6 & 7 & 3 & 3 & 5 & 5 & 2 \\
\hline November & 5 & 4 & 4 & 2 & 3 & 2 & 3 & 1 \\
\hline December & 6 & 5 & 6 & 6 & 5 & 3 & 4 & 4 \\
\hline Total & $\mathbf{6 3}$ & $\mathbf{6 8}$ & $\mathbf{6 1}$ & $\mathbf{5 1}$ & $\mathbf{4 0}$ & $\mathbf{4 4}$ & $\mathbf{4 2}$ & $\mathbf{3 4}$ \\
\hline Total, \% & & & & & $\mathbf{6 3}$ & $\mathbf{6 5}$ & $\mathbf{6 9}$ & $\mathbf{6 7}$ \\
\hline
\end{tabular}

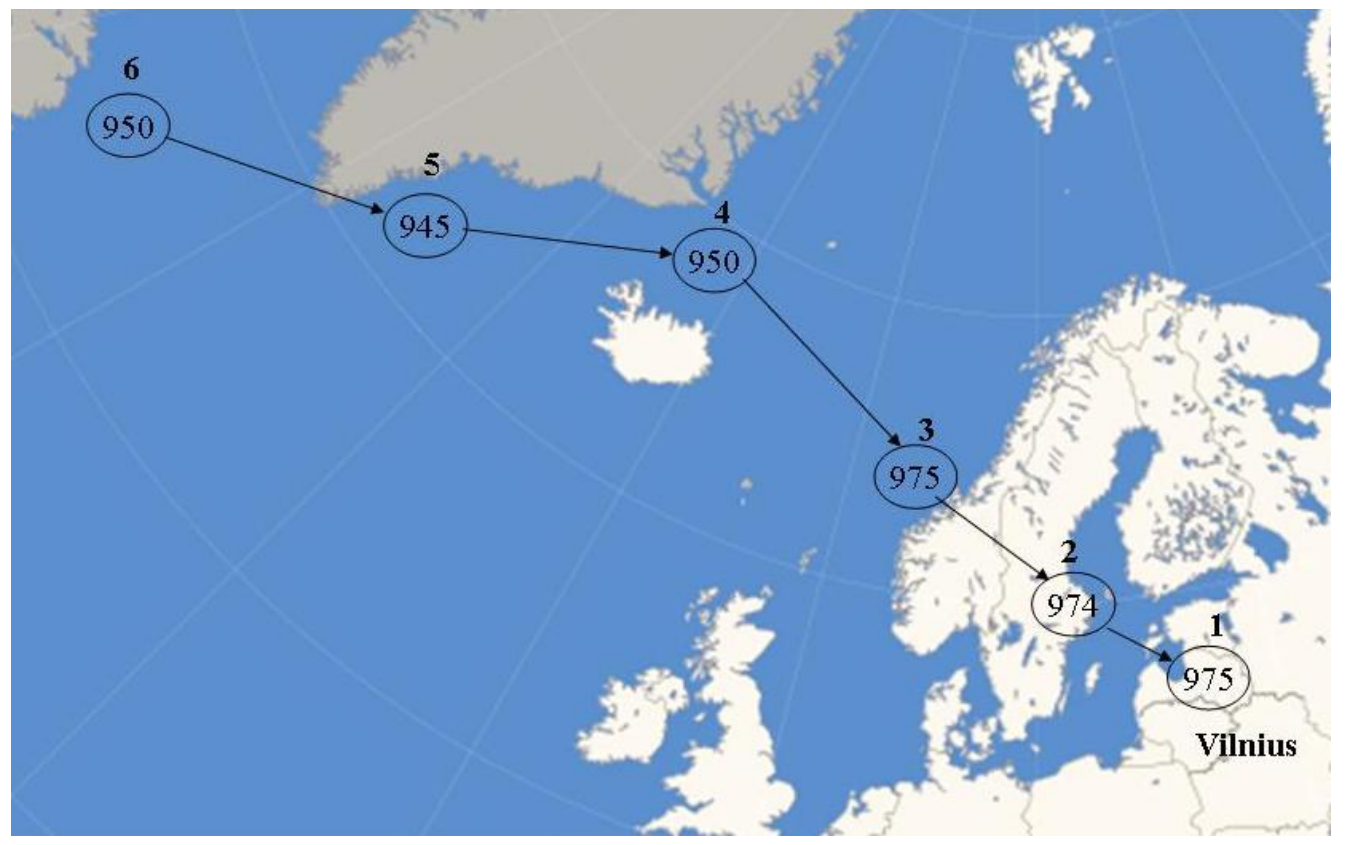

Fig. 2. Cyclone transfer from Newfoundland towards Vilnius city. Number in circles is atmospheric pressure in hPa. Figures 6-1 mean days and formation of minimum atmospheric pressure on January 21-22, 2005

The first signal of HCRF decrease of $-26 \mathrm{imp} / \mathrm{h}$ was registered at a time interval of 12-13 hours on January 16 , 2005, when a cyclone at Newfoundland started its transfer eastward (Fig. 2). It means that minimum atmospheric pressure in Vilnius would be on January 21-22. The next signal of $-21 \mathrm{imp} / \mathrm{h}$, registered at a time interval of 9-10 hours on January 17, confirmed the formation of minimum atmospheric pressure by this cyclone in Vilnius, too. On January 19, a signal of $-17 \mathrm{imp} / \mathrm{h}$ was obtained at a time interval of 8-9 hours (Fig. 2). All these signals predicted the minimum atmospheric pressure $(979 \mathrm{hPa})$ in Vilnius after 5-6 days, i. e. on January 21-22, 2005 (Fig. 2).

Thus, the signals of HCRF decrease depending on their registration time define the minimum atmospheric pressure in the observation station (Vilnius) in 6-3 days after the cyclone formation in the North Atlantic.

\section{Discussion}

It is well known that connection between atmospheric dynamic processes and secondary cosmic radiation changes near the ground surface (Стыро 1983, 1984; Styro et al. 2005, 2007). Primary cosmic ray flux is coming out from the Galaxy, interact with atmospheric gas atoms and generate nuclear reactions. Since primary cosmic particles, protons and $\alpha$-particles, have an electric charge, therefore, passing through a geomagnetic field they loose their energy towards the Earth. Primary cosmic ray flux cannot reach the ground surface because protons make about 15 collisions with atmospheric gas atoms. That is why secondary cosmic ray flux is registered only near the ground surface. 
It is natural that secondary cosmic ray flux variations, on the one hand, reflect geomagnetic field variations and, on the other hand, - atmospheric process changes.

In this study we investigated the relationship between HCRF change at 1.2-1.6 MeV energy interval and atmospheric pressure variations. To analyse this correlation HCRF was chosen to separate the soft part of cosmic flux because the latter can be formed by non-cosmic factors. Thus only muon flux was registered by a gamma spectrometer.

The variation of HCRF and atmospheric pressure had a strong inverse correlation during two years if measurements were carried out in the same day. Such a connection is natural. During cyclone motion over the observation station atmospheric pressure decreases and at the same time air density decreases and more cosmic particles can reach the ground surface. In the case of an anti-cyclone the situation is inverse.

However, HCRF variations at individual time intervals (Tables 3,4 ) vary from average daily values. It is found that minimum atmospheric pressure prognosis in Vilnius by HCRF decrease in 3-6 days is possible at various time intervals (Стыро 1984). Prognostic correlation between the above mentioned parameters was found at each time interval, i. e. 8-9, 9-10, 11-12, 12-13 hours in 2004 and 2005. The efficiency of prognosis was 59$73 \%$.

Why were the negative results of $27-41 \%$ obtained in this case? To explain these facts, on the one hand, it is necessary to analyse natural effects on measuring installation and, on the other hand, atmospheric process change over the observation station.

Thunderstorm effect forms high-energy particle flux moving towards the ground surface and influencing a gamma spectrometer (Стыро 1984; Стыро, Астраускене 1988). Solar flashes also change cosmic particles flux near the ground surface (Богданович, Стыро 1988). Moving anti-cyclones often block the path of cyclones changing atmospheric pressure above the observation station (Стыро 1984). Thus it is problematic to get efficiency of prognosis up to $100 \%$ using this method.

Information about minimum atmospheric pressure formation in 5-6 days in Vilnius, when a cyclone was moving from Newfoundland eastward, was registered at a time interval of 12-13 hours (-26 imp/h.) (Fig. 2).

This result was confirmed on 17 Jan. (Fig. 2) at a time interval of $11-12$ hours (-21 imp/h.), so minimum atmospheric pressure would be after 4-5 days in Vilnius. Cyclone change and transfer to the minimum atmospheric pressure (979 hPa) on 21-22 Jan. is illustrated in Fig. 2 in 5-6 days in Vilnius after the first registration of HCRF decrease.

The obtained results confirm that atmospheric pressure minimum values prognosis in Vilnius by HCRF decrease at an energy interval of $1.2-1.6 \mathrm{MeV}$ at a time interval of 8-13 hours is possible in up to 6 days.

Similar data of 2002-2003 (Styro et al. 2008) confirm the results and tendency of the present investigation.

\section{Conclusions}

1. Inverse correlation between hard cosmic ray flux (HCRF) and atmospheric pressure variations was determined during simultaneous measurements. The strongest negative correlation is in winter.

2. Prognostic connection between HCRF and atmospheric pressure decrease at $1.2-1.6 \mathrm{MeV}$ energy interval was found.

3. The highest accuracy of the results was $73 \%$ at $9-10$ hour interval of time in 2004.

4. The prognostic connection efficiency between hard cosmic ray flux and atmospheric pressure change was almost the same at all the time intervals in 2005.

5. HCRF decrease at various time intervals is determined by the influence of cyclones which are formed in different areas of the North Atlantic.

\section{References}

Galvonaitė, A.; Misiūniené, M.; Valiukas, D.; Buitkuvienè, M. S. 2007. Lithuanian climate: Monograph 207 p. [in Lithuanian].

Hill, T.; Lewicki, P. 2007. Statistics methods and applications. Statsoft, Tulsa.

Kovaltsov, G. A.; Usoskin, I. G. 2007. Regional cosmic ray induced ionization and geomagnetic field changes, Advances in Geosciences 13: 31-35. doi:10.5194/adgeo-13-31-2007

Roldugin, V. C.; Tinsley, B. A. 2004. Atmospheric transparency changes associated with solar wind-induced atmospheric electricity variations, Journal of Atmospheric and SolarTerrestrial Physics 66(13-14): 1143-1149.

Starodubtsev, S. A.; Usoskin, I. G.; Mursula, K. 2004. Rapid cosmic ray fluctuations: evidence for cyclic behaviour, Solar physics 224: 335-343. doi:10.1007/s11207-005-4178-4

Styra, D.; Čiučelis, A.; Usovaitè, A.; Damauskaitė, J. 2008. On possibility of short-term prognosis of cyclonic activity after-effects in Vilnius by variation of hard cosmic rays flux, Journal of Environmental Engineering and Landscape Management 16(4): 159-167. doi:10.3846/1648-6897.2008.16.159-167

Styro, D.; Gaspariūnas, J.; Usovaite, A. 2004. Peculiarities of hard cosmic radiation variations near the ground surface in accordance with geomagnetic activity changes, Journal of Environmental Engineering and Landscape Management 12(3): 96-102.

Styro, D.; Gaspariūnas, J.; Usovaitė, A.; Juozulynas, A. 2005 On connection between hard cosmic ray flux variation and changes in cardiovascular diseases in Vilnius city, International Journal of Biometeorology 49: 267-272. doi:10.1007/s00484-004-0230-6

Styro, D.; Usovaitė, A.; Damauskaite, J. 2007. On connection between hard cosmic ray flux and atmospheric pressure variations, in The 7th International Conference "Environmental Engineering”: Selected papers (22-23 May 2007, Vilnius, Lithuania) 1: 368-373.

Svensmark, H. 1998. Influence of cosmic rays on Earth's climate, Physical Review Letters 81: 5027-5030. doi:10.1103/PhysRevLett.81.5027

Usoskin, I. G. 2004. Long-term variations of cosmic rays and terrestrial environment, Frontiers of Cosmic Ray Science, 205-228. 
Usoskin, I. G.; Kovaltsov, G. A. 2008. Cosmic rays and climate of the Earth: possible connection, Comptes Rendus Geosciences 340(7): 441-450. doi:10.1016/j.crte.2007.11.001

Yashin, I. I.; Barbashina, N. S.; Borog, V. V.; Capdevielle, J.-N.; Kokoulin, R. P.; Petrukhin, A. A.; Saavedra, O.; Timashkov, D. A.; Shutenko, V. V. 2006. Muon diagnostic of magnetosphere and atmospheric of the Earth, in $20^{\text {th }}$ European Cosmic Ray Symposium (ECRS) in Lisbon, Portugal.

Береснев, А. А.; Леонов, В. В.; Павилович, Ч. С.; Стыро, Д. Б. 1988. О колебаниях фона гамма-спектрометрической аппаратуры в различных временных интервалах [On the background fluctuations of gamma-spectrometric devices of varying time intervals], Физика атмосферы 12: 191-206.

Богданович, А.; Стыро, Д. Б. 1988. О возможном воздействии Солнца на поток жесткого космического излучения у земной поверхности [On the supposed Sun's influence on hard cosmic ray radiation near the Earth's surface], Физика атмосферы 12: 30-34.

Сивинцев, Ю. В.; Нежданов, Г. А.; Ковальчук, Е. Л.; Воронин, К. В.; Пугачёв, С. П. 1980. Основные составляющие фоновой скорости счёта большого сцинтилляционного детектора [Principal components of background counting of big scintillation detector], Атомная энергия 49(1): 45-49.

Стыро, Д. Б. 1983. О возможности прогноза перемещения барических полей по вариациям жесткого косми- ческого излучения [On the possibility of pressure field transfer forecast by hard cosmic radiation variations], $\Phi u$ зика атмосферы 8: 95-103.

Стыро, Д. Б. 1984. О предсказании колебаний атмосферного давления по вариациям жесткого космического излучения [On barometric pressure variation forecast by hard cosmic ray flux instability], Физика атмосферы 9: 96102.

Стыро, Д. Б.; Астраускене, Н. 1988. Прогноз метеорологических процессов по колебаниям жесткого космического излучения [Forecast of meteorological processes according to hard cosmic ray flux instability], Физика атмосферы 12: 20-30.

Стыро, Д. Б.; Гаспарюнас, Й.; Усовайте, А. 2003. Поиск оптимального метода и энергетического диапазона жесткого космического излучения для прогноза изменения сердечно-сосудистых заболеваний [Optimum method and range of energies of hard cosmic radiation discover to predict the cardiovascular diseases change], Вестник МАНЕБ 8(1): 89-94.

Стыро, Д. Б.; Сивинцев, Ю. В. 1983. О времени суток для оптимальной регистрации слабоактивных источников методом гамма-спектрометрии [On the measurements time of optimum registration of low activity sources by gamma-spectrometry], Физика атмосферы 8: 104-107.

\section{KIETOSIOS KOSMINĖS SPINDULIUOTĖS SRAUTO IR ATMOSFEROS SLĖGIO SEZONINĖS KAITOS 2004-2005 m. IVERTINIMAS}

\section{Styro, J. Damauskaitė, J. Kleiza}

Santrauka

Straipsnyje analizuojamas kietosios kosminės spinduliuotės srauto (KKSS) ir atmosferos slėgio pokyčių sąryšis. KKSS buvo matuojamas gama spektrometru su scintiliaciniu jutikliu. Išsamią meteorologinę informaciją pateikè Lietuvos hidrometeorologijos tarnyba. Koreliacijos koeficientai apskaičiuoti taikant tiesinę regresiją tarp KKSS ir atmosferos slėgio pokyčių. Nustatyta stipri atvirkštinė koreliacija, kai matavimai atlikti tą pačią dieną. Gauti skirtingi îvairių metų sezonų koreliacijos koeficientai. Atliekant KKSS mažèjimo analizę buvo parinktas empirinis kriterijus -20 imp./h. Nustatytas sąryšis tarp KKSS mažèjimo 1,2-1,6 MeV energetiniame intervale ir atmosferos slėgio mažèjimo po 3-6 parų Vilniuje. KKSS mažèjimas buvo analizuojamas per 8-9, 9-10, 11-12, 12-13 val. laiko intervalus. 2004-2005 m. atmosferos slègio mažèjimo prognozès efektyvumas Vilniuje pagal KKSS mažèjimą buvo 59$73 \%$.

Reikšminiai žodžiai: kosminiai spinduliai, atmosferos slègis, koreliacijos koeficientas, sąryšis.

\section{ОЦЕНКА СЕЗОННЫХ ИЗМЕНЕНИЙ ПОТОКА ЖЕСТКОГО КОСМИЧЕСКОГО ИЗЛУЧЕНИЯ И АТМОСФЕРНОГО ДАВЛЕНИЯ В 2004-2005 ГГ.}

\section{Д. Стыро, Й. Дамаускайте, Й. Клейза}

Резюме

Анализируется связь между изменениями потока жёсткого космического излучения (ПЖКИ) и атмосферного давления. ПЖКИ определялся с помощью гамма-спектрометра со сцинтилляционным детектором. Подробная метеорологическая информация была прегоставлена гидрометеорологической службой Литвы. Коэффициенты корреляции между колебаниями ПЖКИ и атмосферного давления были рассчитаны методом прямой регрессии. Установлена сильная обратная корреляция для тех случаев, когда измерения проводились одновременно. Значения коэффициентов корреляции оказались различными для разных сезонов года. При проведении анализа уменьшения ПЖКИ был выбран эмпирический критерий - 20 имп/час. Установлена прогностическая связь между уменьшением ПЖКИ в энергическом интервале 1,2-1,6 МэВ и уменьшением атмосферного давления через 3-6 суток в г. Вильнюсе. Уменьшение ПЖКИ рассматривалось в следующих временных интервалах: 8-9, 9-10, 11-12, 12-13 час. Эффективность прогноза уменьшения атмосферного давления в г. Вильнюсе по уменьшению ПЖКИ составила 59-73\% в 2004-2005 гг.

Ключевые слова: поток жесткого космического излучения, атмосферное давление, коэффициент корреляции, связь. 
Dmitrijus STYRO. Dr Habil, Prof. Dept of Physics, Vilnius Gediminas Technical University (VGTU).

Doctor Habil of Natural Sciences (physics and mathematics), Sevastopol Marine Hydrophysical Institute (1984). Doctor of Natural Sciences (physics and mathematics), Vilnius University (1968). Publications: author of over 200 scientific publications. Conferences: participant of over 100 international and national conferences. Research interests: nuclear hydrophysics, radioecology and predictions of anomalous effects on the Earth.

Jovita DAMAUSKAITÉ. Doctoral student, Dept of Physics, Vilnius Gediminas Technical University (VGTU).

Doctoral student (environmental engineering), VGTU, since 2006. Master of ecology, VGTU, 2006. Publications: co-author of 5 research papers. Conferences: participant of 2 international and 6 national conferences. Research interests: ecology, environmental protection.

Jonas KLEIZA. Dr, Assoc. Prof., Dept of Mathematical Modelling, Vilnius Gediminas Technical University (VGTU).

Doctor of Mathematical Sciences, 1974. First degree in Mathematics, Vilnius University (1969). Publications: author of more than 50 scientific publications. Conferences: participant of over 40 international and national conferences. Research interests: artial differential equations, mathematical modelling. 